\title{
THE CONSTITUTIONALITY OF RETROACTIVE TRUSTEE COMPENSATION STATUTES IN PENNSYLVANIA
}

Changes in Pennsylvania trustee compensation statutes have raised two questions regarding the constitutionality of their retroactive application. First, whether a life tenant's right to the trust income would be unconstitutionally infringed if the trust corpus, and thereby the trust income, were reduced by the award of a principal commission to a trustee earlier than would have been permitted under the case law existing when the trust was established. Second, whether the remainderman's right to the trust corpus would be unconstitutionally infringed by the award of a second principal commission to an executor-trustee who had received one "full" principal commission before the repeal ${ }^{1}$ of a statute limiting him to a single commission on the principal of a trust estate. ${ }^{2}$

Under the repealed statute, the single commission which an executortrustee was permitted to collect on the principal of a trust estate was awarded to him at the executor's accounting. ${ }^{3}$ It was computed with reference to his future duties as trustee as well as his past duties as executor. ${ }^{4}$ Thus a part of the executor-trustee's compensation was paid in advance of his duties as a trustee. In the future he could expect to receive only a moderate commission on trust income. ${ }^{5}$ In contrast, a trustee who was not also an executor was required by case law to wait for his commission on the principal of the trust until the termination of either the
$1 \mathrm{~Pa}$. Laws 1945, No. 90.
2 Pa. Laws 1917, No. 193, § 45 :
In all cases when the same person shall, under a will, fulfill the duties of executor and trustee, it shall not be lawful for such person to receive or charge more than one commission upon any sum of money coming into or passing through his hands, or held by him for the benefit of other parties; and such single commission shall be deemed a full compensation for his services in the double capacity of executor and trustee: Provided, That any such trustee shall be allowed to retain a reasonable commission on the income he may receive from any estate held by him in trust as aforesaid.

3 Middleton's Estate, $66 \mathrm{~Pa}$. Super. 55, 61-62 (1917); Milliken's Estate, $36 \mathrm{~Pa}$. County Ct. 187, 189-90 (Schuylkill County Orphans' Ct. 1909) ; Moore's Estate, 13 Pa. Dist. 137, 140 (Philadelphia Orphans' Ct. 1904), aff'd, 211 Pa. 343, 60 Atl.' 989 (1905). Whether an election not to request the principal commission at the executor's accounting would have constituted an implied waiver is a close question. Probably it would not. See Coulter Estate, 379 Pa. 209, 108 A.2d 681 (1954); Van Storch Estate, $88 \mathrm{~Pa}$. Super. 43 (1926) i But see Scull's Estate, $249 \mathrm{~Pa}$. 57, 61, 94 At1. 476, 477 (1915); Horwitz Estate, 7 Pa. Dist. 179 (Philadelphia Orphans' Ct. 1898) (dictum). The practice of requesting the principal commission at the executor's accounting was so well established, however, that no election in the true sense of that word could be said to occur.

4 See, e.g., Quigley's Estate, 329 Pa. 281, 295, 198 At1. 85, 91 (1938) ; Middleton's Estate, 66 Pa. Super. 55, 61-62 (1917); Rogers's Estate, 17 W.N.C. 29, 30 (Philadelphia, Pa. Orphans' Ct. 1885) ; Barclay's Estate, 2 W.N.C. 447, 448 (Philadelphia, $\mathrm{Pa}$. Orphans' Ct. 1876).

5 This was usually $5 \%$ of the annual income. 1 Hunter, Penssylvania ORPHaNs' Court CoMmonplace Book 270 (2d ed. 1959). 
trust or his relation to the trust. ${ }^{6}$ A large part of his compensation was therefore postponed until all his duties were completed. In the meantime he collected the same moderate commission on trust income as did the executor-trustee.

Neither rule proved satisfactory. Trustees complained because their commissions on principal were postponed. Frequently an individual, as opposed to a corporate, trustee failed to outlive the trust, so that his principal commission was not awarded until after his death. ${ }^{7}$ Executortrustees, on the other hand, were dissatisfied because their principal commission seemed inadequate in retrospect. Furthermore, the payment of a large sum in a single year had unhappy tax consequences for both trustees and executor-trustees.

Against this background, the Pennsylvania legislature in 1945 repealed the statute limiting executor-trustees to a single principal commission. ${ }^{8}$ Corporate fiduciaries advocated changes in the case law, particularly the introduction of a "pay as you go" system of periodic compensation from principal to match the regular commissions on income. ${ }^{9}$ In Williamson Estate, ${ }^{10}$ a test case brought in 1951, the Pennsylvania Supreme Court admitted that a reform of the rules governing trustee compensation might be desirable, but suggested that the matter was properly one for the legislature. $^{11}$ The court declined to overrule the case law prohibiting the payment of a principal commission to a trustee before either the termination of the trust or his relation to the trust. ${ }^{12}$ In the alternative the court held that the payment of a second principal commission to the executortrustee, who had accepted the trust and been paid a "full" principal commission before repeal, would infringe upon the remainderman's right to the trust corpus in violation of the fourteenth amendment to the United States Constitution. ${ }^{13}$ In 1953, not long after Williamson, the Pennsylvania legislature passed a statute which provided:

6 Snyder Estate, 346 Pa. 615, 622-23, 31 A.2d 132, 136 (1943) ; Bosler's Estate, $161 \mathrm{~Pa}$ 457, 462-67, 29 Atl. 57, 60-62 (1894) (per curiam).

7 See Williamson Estate, 70 Pa. D. \& C. 230, 232-33 (Philadelphia Orphans' Ct. 1950), aff'd, 368 Pa. 343, 82 A.2d 49 (1951).

8 Pa. Laws 1945, No. 90 (repealing Pa. Laws 1917, No. 193, § 45).

9 See Williamson Estate, $368 \mathrm{~Pa}$. 343, 348, 82 A.2d 49, 52 (1951); 86 Trusts \& Estates 46 (1948); 84 Trusts \& Estates 84 (1947).

$10368 \mathrm{~Pa} .343,82$ A.2d 49 (1951).

11 Id. at 352,82 A.2d at 54 .

12 Id. at $350-52,82 \mathrm{~A} .2 \mathrm{~d}$ at $53-54$

13 Id. at $352-53,82 \mathrm{~A} .2 \mathrm{~d}$ at 54 . The case involved both issues since the executortrustee had received a "full" principal commission at the executor's accounting and was requesting a second principal commission before the termination of the trust. The lower court refused the request solely because the trust had not yet terminated. Williamson Estate, $70 \mathrm{~Pa}$. D. \& C. 230 (Philadelphia Orphans' Ct.), aff'd, $368 \mathrm{~Pa}$. 343,82 A.2d 49 (1951). The supreme court asked for briefs and reargument on the question of whether a second principal commission would be constitutional. The decision to refuse the fiduciary's request for a principal commission could have been sustained independently for either of these two reasons.

On the constitutional question, neither Williamson nor later cases refer to $\mathrm{PA}$. CoNst. art. 1, $\S 1,9$, whose language is substantially similar to U.S. CoNST. amend. XIV, §1. 
Section 1. Neither the fact that a fiduciary's service has not ended nor the fact that the trust has not ended shall be a bar to the fiduciary's receiving compensation for his services out of the principal of a trust.

Section 2. Whenever it shall appear either during the continuance of a trust or at its end, that a fiduciary has rendered services for which he has not been fully compensated, the court having jurisdiction over his accounts shall allow him such original or additional compensation out of the trust income or the trust principal or both, as may be necessary to compensate him for the services theretofore rendered by him.

Section 5. This act shall apply:

(1) To all services heretofore rendered by any fiduciary;

(2) To all services hereafter rendered by any fiduciary heretofore appointed;

Section 6. If the Constitution of the United States or of this Commonwealth prevents the application of this act to services falling in one or more of the four categories listed in section 5 hereof, the act shall nevertheless apply to services falling in the other categories or category. ${ }^{14}$

Thereafter, lower courts awarded interim principal commissions to trustees who would previously have been required to wait until the termination of the trust. ${ }^{15}$ But in Scott Estate, ${ }^{16}$ where an executor-trustee who had received a principal commission before the repeal applied for a second principal commission on the authority of section 2 of the new statute, the Pennsylvania Supreme Court followed its decision in Williamson and held that such an award would unconstitutionally infringe upon the remainderman's right to the trust corpus.

The majority of the court in Williamson had argued that when the trust was accepted and the first principal commission awarded, an implied

14 PA. Stat. Ann. tit. 20, §§ 3274, 3275, 3278(1) (2), 3279 (1964).

15 Rea Trust, 28 Pa. D. \& C.2d 433 (Montgomery County Orphans' Ct. 1962); Colton Estate, 11 Pa. D. \& C.2d 538 (Montgomery County Orphans' Ct. 1957); Mifflin Trust, 4 Fiduciary Rep. 275 (Philadelphia, Pa. Orphans' Ct. 1954) ; Stotesbury Estate, 85 Pa. D. \& C. 551 (Montgomery County Orphans' Ct. 1953), rev'd on other grounds, $387 \mathrm{~Pa} .591$ (1957).

$16418 \mathrm{~Pa} .332,211$ A.2d 429 (1965). The fiduciaries in Scott argued that reference to the constitutional issue in Williamson had been dicta. In view of the fact that the Williamson court had asked for separate briefs and reargument on the issue, the statement certainly had none of the weaknesses of dictum. In any case, whether it was dictum or an alternative holding, the court in Scott found it "persuasive and applicable." Id. at $337-38,211$ A.2d at 432 . 
contract was formed. 'One term of this contract was that the single principal commission, in accordance with the statute then in effect, would be in full compensation for the executor-trustee's past and future services. Under this implied contract, the Williamson opinion concluded, the remainderman had a vested right to the trust principal which would be unconstitutionally infringed by the award of a second principal commission. ${ }^{17}$ A separate opinion in Williamson, ${ }^{18}$ filed by Justice Bell, answered that if any implied contract were formed, it was one providing that the executor-trustee would be paid reasonable and just compensation for his services. ${ }^{19}$ He concluded that no vested right would be infringed by the award of a second principal commission if one were necessary to compensate the fiduciary adequately for the services rendered subsequent to the repeal. ${ }^{20}$

Both the majority opinion in Williamson and the separate opinion by Justice Bell do little more than assert their conclusions that a vested right will or will not be infringed by allowing a second commission on principal. The label "vested" is not itself an explanation. Its only definition in this context is that a right so labeled is constitutionally protected from infringement by a retroactive law; ${ }^{21}$ thus to say that a law may not be applied retroactively because it infringes a vested right is circular. Nor does the introduction of an implied contract contribute to an analysis of the constitutional problem. An interest is not protected from the operation of a retroactive law simply because it is associated with a contract.22

Since a number of jurisdictions have upheld the constitutionality of retroactive trustee compensation statutes, ${ }^{23}$ it is important to determine whether the decisions in Williamson and Scott were correct, and whether the constitutional argument for allowing interim principal commissions on trusts established under the terminal principal commission rule depends on the same, or different, considerations.

Basic to the constitutional question is a determination of the intent of the 1953 statute. Clearly the legislature intended that interim principal

$17368 \mathrm{~Pa}$. at $352,82 \mathrm{~A} .2 \mathrm{~d}$ at 54.

18 Id. at $353,82 \mathrm{~A} .2 \mathrm{~d}$ at 54 .

$19 \mathrm{Id}$. at $360,82 \mathrm{~A} .2 \mathrm{~d}$ at 58 .

20 Ibid. Justice Bell concluded that the repeal was intended to be prospective only, but argued that the provision in the repealing act that it should take effect immediately showed an intent to apply it to services rendered after the repeal. He then reached the issue of whether, before the repeal, the remainderman had acquired a right to receive services rendered after the repeal without additional charge which would be unconstitutionally infringed by the award of a second principal commission. He concluded that the remainderman had no such right.

212 AUSTIN, JuRISPRUdENCE 256 (Campbell ed. 1875); B. Smith, Retroactive Laws and Vested Rights, 5 Texas L. REv. 231, 245-48 (1927).

22 See, e.g., Home Bldg. \& Loan Ass'n v. Blaisdell, 290 U.S. 398 (1934) ; Hale, The Supreme Court and the Contract Clanse: III, 57 HARv. L. REv. 852, 872-92 (1944).

23 E.g., Estate of Franklin, 47 Cal. 2d 303, 303 P.2d 339 (1956) (per curiam); In re Donovan's Estate, 266 Mich. 362, 253 N.W. 552 (1934); Robertson v. DeBrulatour, 188 N.Y. 301,80 N.E. 938 (1907). 
commissions should be allowed on trusts established before its enactment. There is, however, some doubt that the legislature intended to authorize the payment of second principal commissions to executor-trustees who had collected one before repeal of the statute limiting them to a single commission on principal. The 1945 repealing act itself did not clearly indicate an intent to disturb interests previously settled by the payment of a "full" principal commission. ${ }^{24}$ The remainderman in Scott argued that section 2 of the 1953 statute was directed solely to interim principal commissions and did not refer to executor-trustees who had collected a principal commission under the repealed statute. This construction is plausible. The new statute authorizes additional compensation when it appears that the fiduciary has rendered services "for which he has not been fully compensated . . . "25 Under the language of the repealed statute, the executor-trustee's first principal commission was awarded "in full compensation for his services in the double capacity of executor and trustee. . . ." 26 The continuing reference to "fullness" may indicate a statutory word of art, to be distinguished from "adequate." Nothing else in the statute compels a conclusion that previously paid "full" commissions should be redetermined.

In both Scott and Williamson, however, the court did not rest its decision on the legislature's failure to use compelling language. Instead of strictly construing the retroactive statute, the court dealt directly with the issue of whether it could constitutionally be applied to the trusts.

When a retroactive civil law abridges private interests by changing the legal effect of events which preceded its enactment, it is frequently challenged either as an impairment of the obligation of contracts or as a taking of property without due process of law. Generally it is recognized that the asserted right will be protected from infringement only if, on balancing the purpose served by the retroactive law against the private interests infringed, the law is found to be unreasonable. ${ }^{27}$

The purpose of awarding a second principal commission to an executortrustee who collected one under the repealed statute presumably would be to compensate for any inadequacy of the first, "full" principal commission. In Williamson the corporate fiduciary presented a considerable body of financial data and expert opinion in an attempt to prove a loss both on the operation of its trust department as a whole and on the individual trusts involved. A concurring opinion in the orphans' court's decision noted that the department's profit and loss statement did not take into account

24 See Pa. Stat. Ann. tit. 46, §596 (1952); 1 Sutherland, Statutory ConSTRUCTION $\$ 2044$ (3d ed. 1943).

25 Pa. Stat. Ann. tit. 20, §3275 (1964).

$26 \mathrm{~Pa}$. Laws 1917, No. 193, §45.

27 Greenblatt, Judicial Limitations on Retroactive Civil Legislation, 51 Nw. U.L. REv. 540, 561-63 (1956) ; Hochman, The Supreme Court and the Constitutionality of Retroactive Legislation, 73 HARv. L. REv. 692, 694-95 (1960); B. Smith, sipra note 21 , at $247-48$. 
income derived from the substantial deposits of trust funds awaiting investment, and that its small loss rested on expense allocations which, if varied a mere fraction, would have resulted in a showing of profit for the department as a whole. ${ }^{28}$

With respect to individual trusts, too, the inadequacy of the fiduciary's compensation can be doubted. A principal commission awarded at the commencement of a trust is a larger percentage of the value of the corpus than the same percentage would be if withheld until the trust terminates. Since it is paid in advance, it deprives the life tenant of the investment income it would have produced for him, and it should produce the same return for the fiduciary instead. Consequently, the investment return on the commission paid to the executor-trustee should have at least partially offset any increase in the cost of servicing the trust.

In Scott the fiduciaries did not attempt to reproduce the relevant financial data of the type introduced fourteen years before in Williamson. They merely reviewed the services that had been rendered the trust, indicated the inadequacy of the compensation they had received by comparing it with current compensation for such services in other trusts, and asked for a reasonable principal commission to supplement the first. Such a record certainly does not establish that the first principal commission was inadequate, much less the extent of the alleged inadequacy. At best it creates a general impression that the fiduciaries deserve more compensation for their services.

Conceding-as did the opinion in Scott ${ }^{29}$-that the first principal commission "appears" to have been inadequate, the propriety of awarding a second principal commission still depends upon the relative strength of the policies that favor curing the compensation's inadequacy and those that favor protecting the remainderman's interest in the trust corpus from additional charges by the trustee.

Several of the policies that could conceivably be served by curing the inadequacy depend largely upon its extent. If it were severe enough to endanger the continued existence of corporate fiduciary institutions, the value of their professional services to the community would favor the award of a second principal commission. It does not appear, however, that corporate fiduciaries are unable to attract the capital necessary to their continued operation. It might be argued, in favor of curing a less severe inadequacy, that it would be desirable to do so in order to provide an incentive to superior trust management. The result of a trustee's stewardship is one of the acknowledged criteria in Pennsylvania for computing his compensation. ${ }^{30}$ But it is unlikely that a single, reasoned ex-

28 Williamson Estate, 70 Pa. D. \& C. 230, 238-39 (Philadelphia Orphans' Ct. 1951) (Ladner, J., concurring).

$20418 \mathrm{~Pa}$. at $339,211 \mathrm{~A} .2 \mathrm{~d}$ at $432-33$.

30 In re Ashman's Estate, $218 \mathrm{~Pa} .509,511-12,67$ Atl. 841,842 (1907) ; Lovering Estate, 27 Pa. D. \& C.2d 501 (Philadelphia Orphans' Ct. 1962). 
ception to the general rule would defeat the incentive it provides. In any case, it would lessen the incentive to superior management only in the excepted class. Thus the declining number of trusts created prior to the 1945 repeal of the single principal commission rule would be the only ones affected. Even then, the possibility of surcharging erring trustees should insure an acceptable minimum standard of management.

Another possible argument for curing the inadequacy is that the trust beneficiary will be unjustly enriched if the fiduciary is not paid the value of his services. There is some merit in this contention. Historically, however, the fiduciary's position was honorary and it was thought contrary to public policy to permit any compensation for his services. ${ }^{31}$ His modern right to compensation seems to rest on statutory enactment rather than contract principles. This fact must be considered in weighing the force of this argument.

The interest of the trust beneficiary that would be affected by the award of a second principal commission is somewhat different from that which has been affected by the retroactive trustee compensation statutes held constitutional in other jurisdictions. The difference arises from the fact that the retroactive statutes in other jurisdictions were applied to services for which a court had not before determined the proper amount of compensation, ${ }^{32}$ while in the case of the executor-trustee seeking a second principal commission there has been a prior court determination of the value of all the fiduciary's services and an award of that full amount. Even where the application of new rates of compensation to established trusts has been held constitutional, courts have occasionally recognized this distinction. They have refused to apply the new rate to services for which compensation was granted in a past decree, usually on the theory that the awards were res judicata. ${ }^{33}$

The Scott opinion adverts to several of the policies underlying res judicata without using that label. The opinion states that if the court were to allow a reconsideration of the adequacy of the first principal commission, then beneficiaries of trusts which had ended earlier than originally expected would have a reciprocal right to challenge the reasonableness of these past awards. This, the court suggests, would result in a spate of litigation and would place a heavy burden on trustees to prove the cost of services that might have been rendered years ago. The fear of burdensome litigation and the attendant difficulties of proof are themselves part of the recognized rationale of res judicata. ${ }^{34}$

Another reason for applying res judicata to a particular court determination is to fulfill the reasonable expectations of the parties that an

31 Bogert, Trusts and Trustees $\$ 975$, at 278-80 (2d ed. 1962).

32 See, e.g., cases cited note 23 supra.

33 E.g., In the Matter of Barrett's Estate, 124 Misc. 699, 209 N.Y. Supp. 678 (Surr. Ct. 1925).

34 Vestal, Rationale of Prechusion, 9 St. Lours U.L.J. 29, $31-34$ (1964). 
issue should be determined by a court only once. ${ }^{35}$ This seems to favor making the reasonableness of the first principal commission res judicata. When the commission was awarded at the executor's accounting, it was intended by the court and understood by the parties to be in full satisfaction for all the executor-trustee's claims on principal for his past and future services. The remainderman could challenge its reasonableness for only a limited time. ${ }^{36}$ It seems that the executor-trustee should be similarly precluded from questioning the award's reasonableness. ${ }^{37}$ The observation in Scott that if a second principal commission were awarded, then the first should be open to challenges by trust beneficiaries who normally would be barred from doing so, suggests that the court was thinking in terms of res judicata.

The decisions in Scott and Williamson on the issue of second principal commissions apparently rested on the recognized reluctance of a court to allow infringement of a right established in a "final and unreviewable determination." 38 In view of the questionable showing of inadequacy and the lack of compelling reasons for curing it, the decisions in Willianson and Scott seem proper.

The argument for upholding a retroactive application of the interim principal commission statute is significantly stronger than is the case for allowing a second principal commission where the executor-trustee has collected a full commission under the repealed statute. The purpose of awarding an interim principal commission is to compensate the trustee for his services more promptly than was the practice under the terminal principal commission rule. This change is especially advantageous to the individual trustee, who will certainly be more willing to assume his duties knowing that he, rather than his estate, will reap the fruits of his labor. In the case of the retroactive interim principal commission statute, the remainderman has no standing to complain. The trustee is entitled to a principal commission and the fact that it is paid in more than one installment would not seem to affect the total amount of the award. Nor should the slight reduction of income resulting from the early award of a principal commission defeat any reasonable expectations of the income beneficiary, since the amount of income commissions in Pennsylvania has always been at the discretion of the court and subject to variation. ${ }^{39} \mathrm{Be}-$ cause there has not been a final court determination of the amount of the

$35 I d$. at 31 .

${ }^{36}$ McKinney's Estate, 260 Pa. 123, 103 Atl. 590 (1918); Vastine's Estate, 190 Pa. 443, 42 At1. 1038 (1899).

37 The remainderman in Scott argued that there may have been reliance on the fact that the first commission was final. He suggested that the first award might have been challenged within the time allotted for appeal if it were thought that a second principal commission were possible. Brief for Appellee, p. 25.

38 Western Union Tel. Co. v. Louisville \& N.R.R., 258 U.S. 13, 22 (1922) (dictum); see Hochman, supra note 27, at 718-19.

39 Lennig's Estate, $53 \mathrm{~Pa}$. Super. 596 (1913); Gelbach's Estate, $29 \mathrm{~Pa}$. Super. 446 (1905). 
income commissions, the policies behind res judicata do not favor protecting the income beneficiary from such a change. Balancing the purpose served by the retroactive interim principal commission statute against the slight reduction of income from the trust, it seems that the law is clearly reasonable.

The constitutionality of the retroactive interim principal commission statute is not controlled by Scott and Williamson because, as we have seen, different factors enter into the balancing process which determines its reasonableness. For the same reason the decisions in Scott and Williamson are not inconsistent with the Pennsylvania decisions ${ }^{40}$ upholding the constitutionality of the retroactive provisions of the Uniform Principal and Income Act. ${ }^{41}$ Each case poses a unique problem.

The difficulty of predicting the outcome of a balancing test is apparent. If it is thought that retroactive statutes in the area of trust administration are desirable, it might be helpful for a legislature drafting such a statute to explicitly provide that its future amendment may be given retroactive effect. This at least will put the parties affected on notice that the legislature does not intend that any rights acquired under the statute shall be immune from later changes in the rules of trust administration.

40 Norvell Estate, $415 \mathrm{~Pa}$ 427, 203 A.2d 538 (1964), cert. denied, 380 U.S. 913 (1965); Catherwood Trust, 405 Pa. 61, 173 A.2d 86 (1961).

41 PA. Srat. ANn. tit. 20, §3470.15 (1964). 